\title{
inTOXICating FOLLOWERSHIP
}


Wendy Edmonds has made an important and crucial contribution to our understanding of the complex dynamics of toxic followership and how it played out in the Jonestown catastrophe in 1978! Given our own cultist movements in these Trump-influenced times, let us learn from Edmonds's analysis and wisdom!

-Cornel West, Harvard University

Dr. Edmonds presents a work that is exceptional and relevant, especially during our current world situation. She has pinpointed the various aspects of toxic followership which highlights not just one stereotypical view of those who have joined toxic organizations, but several. This will help people recognize what Toxic Followership looks like.

-Leslie Wagner-Wilson, Jonestown Survivor 


\section{inTOXICating FOLLOWERSHIP: in the Jonestown Massacre}

BY

WENDY M. EDMONDS

Bowie State University, USA

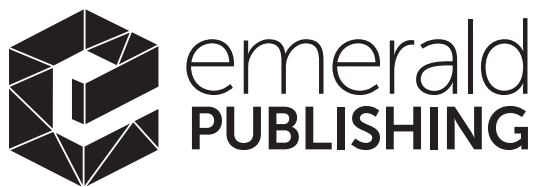

United Kingdom - North America - Japan - India - Malaysia - China 
Emerald Publishing Limited

Howard House, Wagon Lane, Bingley BD16 1WA, UK

First edition 2021

(C) 2021 Wendy M. Edmonds

Published under exclusive licence by Emerald Publishing Limited

Reprints and permissions service

Contact: permissions@emeraldinsight.com

No part of this book may be reproduced, stored in a retrieval system, transmitted in any form or by any means electronic, mechanical, photocopying, recording or otherwise without either the prior written permission of the publisher or a licence permitting restricted copying issued in the UK by The Copyright Licensing Agency and in the USA by The Copyright Clearance Center. Any opinions expressed in the chapters are those of the authors. Whilst Emerald makes every effort to ensure the quality and accuracy of its content, Emerald makes no representation implied or otherwise, as to the chapters' suitability and application and disclaims any warranties, express or implied, to their use.

British Library Cataloguing in Publication Data

A catalogue record for this book is available from the British Library

ISBN: 978-1-80071-459-5 (Print)

ISBN: 978-1-80071-458-8 (Online)

ISBN: 978-1-80071-460-1 (Epub)

ISOQAR certified

Management System,

awarded to Emerald

for adherence to

Environmental

standard

ISOQAR

ISO 14001:2004. 
This book is dedicated to those consumed by your emotions in the role as followers. May this inspire you to no longer subject yourselves to ruthless leaders. It is not uncommon to make an assessment of your encounters. Your experiences will cause you to leverage your own power to escape the domination of predators. 
This page intentionally left blank 


\section{Table of Contents}

List of Figures ix

List of Keywords $x i$

About the Author xiii

Foreword $x v$

Preface xvii

Acknowledgment xix

Introduction 1

Chapter 1 Jim Jones and Peoples Temple 3

Chapter 2 The Leadership-Followership Dynamic: Power and Leadership 11

Chapter 3 The Leadership-Followership Dynamic:

Followership 25

Chapter 4 The Survivors Speak 31

Chapter 5 The Toxic Triangle 41

Chapter 6 Toxic Followership 51

$\begin{array}{ll}\text { Final Thoughts } & 61\end{array}$ 
viii Table of Contents

Restoration

Index

Reflections 


\section{List of Figures}

Figure 5.1. The Toxic Triangle: Elements in Three Domains Related to Destructive Leadership.

Figure 6.1. Toxic Followership Model. (C) 2011 by Wendy M. Edmonds. 
This page intentionally left blank 


\title{
List of Keywords
}

\author{
Toxic followership \\ toxic leadership \\ followership \\ ethical leadership \\ trust \\ power dynamics \\ types of power \\ leader/follower relationships
}


This page intentionally left blank 


\section{About the Author}

Dr. Wendy M. Edmonds, is an Assistant Professor at Bowie State University and Chair of the Followership Learning Community at the International Leadership Association - the largest followership research and practitioner group in the world. Recognized internationally as a scholar-practitioner in followership, an emerging field of study in organizational leadership, Dr. Edmonds is the first researcher to conduct focus group studies with survivors of the 1978 Jonestown Massacre that occurred in Guyana. 
This page intentionally left blank 


\section{Foreword}

In November 1978, when news of a mass suicide of Peoples Temple cult members in Guyana reached Los Angeles, I had already been immersed in another cult for 10 years and would not extricate myself from it for an additional five years.

Of course, we did not consider ourselves to be part of a cult. Probably the members of Peoples Temple didn't either. Rather we were members of a group building a new and much better world. Or so we thought.

That is one of the problems of cult dynamics. There is always a narrative that elevates the experience and makes any of the sacrifices its members make seem rational, even noble. Equally problematic is the loss of the capacity to view the cult leader with any degree of objectivity and certainly not with the slightest hint of criticism.

The reaction to the news of the Jonestown suicides in my group was, "Well, they were obviously a cult. We would never do that!" Or would we? Thankfully, many cults fall short of such a drastic response to the ever threatening "outside" world. But, in retrospect, the conditions and actions we tolerated in our cult held the same grim potential. And, in the broader sense of political cults such as Maoism, Nazism, or Stalinism, the crimes committed and the deaths resulting were many times that of Peoples Temple, as have been the deaths resulting from fanatical religious groups of every denomination.

So, what is going on here?

When I extricated myself from the grip of my cult, I reintegrated into mainstream society. With intentionality, I located myself in Washington, DC, as I instinctively felt that a way to improve the world was through government. Having dropped out of the University of California at Berkeley, I needed to backfill my credentials and entered a degree program in Applied Behavioral Science. There is a lot of emphasis in such a program on group dynamics. I began to reflect on these dynamics as they related to those found in the nonprofits and congressional offices in which I found myself operating, as well as applying them to the more extreme conditions of the cult I had left.

One day I was reading an analysis by M. Scott Peck of the Mỹ Lai massacre in Vietnam. How did hundreds of ordinary Americans participate in this obscenity? Peck observed that when people view themselves in the follower role, they often displace their own accountability for their actions onto the leader. Bingo! That was the missing piece! I wrote in the margin, "It sounds like a book on a new way of following is needed." That was the moment that led me on the journey to writing my first book on followership. 
Like a magnet surrounded by iron filings, I began attracting others who were working with equal fascination and even urgency on aspects of followership. Early among these was Wendy Edmonds. Her doctoral work on Jonestown captivated me. To this day, I am not sure if she knew about my prior cult involvement, as I felt vulnerable about sharing it for many years.

To deeply understand a subject, or even a relationship, one of the ways to get under the superficialities is when it is stress tested. Peoples Temple and Jonestown took leader-follower dynamics to their extreme. The racial and class dynamics involved in this tragedy make it an even more complex case history. Wendy Edmonds has dedicated herself to understanding the lessons of this type of extremity so that we may better recognize, understand, and mitigate its toxic potential.

Make no mistake. The attraction of cults in many forms, tangible and virtual, is all around us. Some of these cults are stridently visible and others are cleverly masked. By taking what she has learned through rigorous academic research and converting the story and its lessons into a widely accessible analysis, Wendy Edmonds has done us a great service. 


\section{Preface}

I toiled in the past several years over how to turn my original research into a book and what to share and how much to share. I continued to wrestle with the emotions that gripped my soul from hearing the survivors' stories of such a horrific life event, people who wanted no more from me except to be their voice in letting others know what it means to be a follower of any kind. They wanted me to reveal toxic followership. Frank, who often spoke about his experience in a poetic fashion, said, "It was the nature of Jim Jones's leadership that defined the nature of my followership; that gave me a larger meaning in my life than I had before or have had since." Hearing him speak those words had the same effect on me as the sound of roaring thunder: it sounded the alarms in my head. Andrea put it like this: "You looked forward to that meeting and everybody gettin' down to the music like they do in Africa, dancing to the beat of the rhythmic drums, even having the bon fires. The music was good." But it was Rob's comment that was the clincher: "It was intoxicating." Clearly, their experience as followers of Jim Jones could be explained as invigorating and exciting, sometimes even diminishing the physical and mental controls of an individual. With that, I give you in TOXICating FOLLOWERSHIP: in the Jonestown Massacre 
This page intentionally left blank 


\section{Acknowledgment}

For all of the late nights, campsite conversations, and long rides traveling on the road you spent listening to me, this is for you. The man of my life who kept me grounded, prayed for me, prayed with me, and believed in me - my husband Warren, thank you.

Thanks to my children who gave me peace during this time.

In memory of my Mommy, and to Daddy, my "Black Gold" who speaks words of wisdom to me daily. Oh, how I cherish you. Thank you.

For my favorite and only brother who has always encouraged me and continues to "build my library," and my sisters who light up a late night with a text that makes me giggle, thank you.

In all of your unique ways, you have helped me. 